УдК 332.2

\title{
ОСОБЛИВІ ПЕРЕДУМОВИ ПОДАЛЬШОГО РОЗВИТКУ РИНКОВИХ ЗЕМЕЛЬНИХ ВІДНОСИН В АГРОЛАНДШАФТАХ УКРАЇНИ
}

\author{
О.І. Ковалів \\ доктор економі них наук, старший науковий співробітник \\ Інститут агроекології і природокористування НААН
}

(Україна, м. Київ; e-mail: okovaliv@ukr.net)

Охарактеризовано сучасний стан природокористування за межами міст України. Розкрито сутність конституиійної норми стосовно права власності Українсъкого народу на землю та їі природні ресурси як на природні об'єкти. Обг рунтовано особливі передумови інституиіонального розвитку ринкових земельних відносин $і$ природокористування в агроландиафтах України як периочергові заходи. Доведено необхідність невідкладного впровадження напрацюванъ земельної ребборми в чинне конституиійне поле України на засадах інституалізацї конституиійних норл стосовно землі та ї̈ природних ресурсів як природних об'єктів права власності Українсъкого народу і основного національного багатства, шо перебуває під особливою охороною держави. Встановлено необхідність проведення ідентифбікаиї й сертифбікаиіï всіх природних об'єктів, які мають природно-заповідну, природоохоронну, оздоровчу, рекреаційну, історико-культурну та іншу иінність. Визначено, що в процесі звериення земельної ребборми в Україні иентральне місце має зайлати просторове прогнозування й моделювання розвитку всіх територій та всіх категорій земель одночасно на всій території держави. Крім того, повинна відбуватися тоталъна діджиталізіиія всіх кроків $і$ наслідків - у часі і просторі. Для зниження ризиків глобального потепління $і$ покращення стану довкілля передбачається залуження та залісення всіх ділянок, шо мають природоохоронне значення. Запропоновано оздоровлення сільсъких територій шляхом формування в сілъсъкій місиевості умов комбортної життєдіяльності для молодих сімей, які зможуть одночасно бути власниками ефективних $i$ заможних землеволодінь $i$ землекористувань сімейного типу (малих $i$ середніх фермерсъких господарств, родових маєтків), щуо також будуть займатися різноманітним екологічно-чистим несільсъкогосподарсъким виробниитвом і підприємництвом.

Ключові слова: конституиійні норми, природокористування, земельна ребборма, земельна дiлянка, земельні паї, прогнозування, земельні інтереси, ринкові земельні відносини.

Постановка проблеми. Усі території за межами міст, що відносяться майже до всіх категорій земель (землі сільськогосподарського призначення займають понад 70\%), уособлюють сукупність об'єктів і систем живої та неживої природи. Конституція України декларує право власності на землю та її природні ресурси як на природні об'єкти права власності Українського народу - основне національне багатство, що перебуває під особливою охороною держави [1].

Ці території прийнято вважати «сільськими», де природні об'єкти і іхні системи взаємодіють між собою і уособлюють, переважно, агроландшафти як складові цілісних екосистем. Досягнення збалансованого природокористування в агроландшафтах відбувається завдяки впровадженню важливих наукових і практичних завдань, що мають загальнонаціональне значення і відповідають конкретним умовам та вимогам розвитку. Доведено, що стале фрунціонування екосистем та відповідного біоценозу в них має пряме відношення до формування всіх сорер комфортної життєдіяльності людини $[2,3]$.
Однак через нівелювання цих вимог і конституційної норми стосовно «права власності на землю» як на природні об'єкти права власності Українського народу і, своєю чергою, звуження розуміння та ототожнення цього конституційного права до норми «права власності на земельну ділянку» як об'єкта цивільних прав, повсюдно відбувається самовільна й системно-монопольна експлуатація олігархічними кланами землі та її природних ресурсів (усіх категорій земель) - як власних.

Унаслідок цього в Україні фрункціонують злочинні схеми і різноманітні афери з усіма, без винятку, корисними копалинами і привабливими земельними ділянками в природних агроландшафтах. Те саме відбувається і з лісами, площа яких займає понад 10 млн га. Торгують не лише кругляком як «дровами» - за валюту, але й знищують природні деревостани, руйнують цілісні екосистеми.

Не у кращому стані перебуває інфраструктура, природно-заповідний фонд, рекреаційні, оздоровчі, природоохоронні та інші землі. Значну загрозу представляють побутові 
смітники, землі, зайняті промисловими відходами, що наближаються до сільських територій. Нищівного впливу на прилеглі території завдають потужні комплекси з промислового вирощування свиней та птиці.

Все це відбувається через відсутність науково-обгрунтованої, економічно вмотивованої земельної рефрорми щодо всіх категорій земель як природних об'єктів права власності Українського народу, зокрема і в агросорері, яка була підмінена трансорормацією колгоспно-радгоспних земельних відносин на основі запровадження колективної фрорми власності на землю в уточненій Конституції УРСР [4].

Нині родючі грунти площею понад 20 млн га також експлуатуються за безцінь.

Таке непрогнозоване безчинство, перетворило переважну більшість селян-пайовиків на віртуальних орендодавців. Замість селянських чи фермерських господарств, на зразок європейських, з'явилися непередбачувані й непрогнозовані великі за розміром бізнес-структури на орендній основі, зокрема агрохолдинги, які вільно здійснюють корпоративні торги, у т.ч. й земельними активами. У державі самочинно відбулися значні структурні зміни в землекористуванні. Звичним, мусимо констатувати, стало беззаконня й рейдерство.

У погоні за наживою українські чорноземи бездумно виснажуються, що спричиняє високі темпи ерозії грунтів, безповоротне зниження їх природної родючості і руйнування водорегулювальної здатності. Загалом, забруднюється і деградує довкілля, зникають природні ландшафрти разом із рідкісною рослинністю, водними джерелами, тваринами, птахами, комахами та корисною мікробіотою. В Україні постала катастрофрічна проблема 3 питною водою - 3 її якістю і мінливим обсягом (затоплення - посуха). Зникають не лише джерела й струмки, а й сільські помешкання та цілі поселення, особливо віддалені від мегаполісів, що спричиняє зникнення селянства як основного складника генофронду нації.

Загалом, щорічні збитки держави від такої «діяльності» на сільських теренах сягають понад 140 млрд дол. США.

До цього слід додати корумпованість всіх сорер життєдіяльності, свавілля чиновників, наявність тіньової економіки і посередництва, боргових зобов'язань, одержання необгрунтованих невиробничих надприбутків, нестабільність національної валюти і банківської системи, відсутність дешевого довгострокового кредитування, системи контролю та невідворотності покарання за правопорушення і недотримання чинного законодавства.
Все це стало одним із базових чинників некерованості у природокористуванні, руйнуванні державності та доведення до зубожіння переважної більшості українців, особливо селян. Усі наявні проблеми слід віднести до загальнонаціональних, що потребують системного і комплексного врегулювання, усунення чинників їх виникнення на основі відповідних конституційних норм прямої дії. Їх розв' язання відноситься до надважливих наукових і практичних завдань державотворення, створення умов раціонального природокористування та фрормування комфортних умов життєдіяльності громадян України у межах власної держави i, насамперед, у конкретних агроландшафртах сільської місцевості як цілісних екосистем.

Аналіз останніх досліджень і публікацій. Численні сучасні наукові теоретичні та методичні дослідження і публікації низки науковців (П.І. Гайдуцького, Д.С. Добряка, Й.М. Дороша, В.М. Заяця, А.Г. Мартина, В.Я. Месель-Веселяка, Л.Я. Новаковського, Б.Й. Пасхавера, П.Т. Саблука, А.М. Третяка, M.M. Федорова, О.І. Шкуратова та ін.) стосовно подальшого розвитку ринкових земельних відносин у агроландшафтах України зводяться, переважно, до вивчення еколого-економічного стану використання й охорони земель та пошуку шляхів удосконалення земельних відносин з метою економічного обігу земель сільськогосподарського призначення, у т.ч. розпайованих, на засадах різноманітних обмежень, обтяжень та стимулювань збалансованого землекористування і підвищення продуктивності земельноресурсного потенціалу. На думку авторів, у такий спосіб досягається, начебто, ефективне функціонування системи екологічної безпеки в аграрному секторі економіки і пріоритетний соціально-економічний розвиток села, що уможливить запровадження регульованого ринку цих земель [5-8].

Також значна увага увага приділяється вивченню характеристики земельних ресурсів як аграрних у системі земельного кадастру, ї оцінюванню, віднесенню до особливо цінних, фрормуванню ринкової інфраструктури на конкурентній основі, переважно на засадах квазіінвестиційного агробізнесу, який, буцімто, забезпечуватиме сталий розвиток сільських територій [9-11].

На жаль, цього не відбувається дотепер, оскільки науковцями і вченими було цілковито залишено поза увагою (до проголошення незалежності України - 1991 та до прийняття Конституції України — 1996) необхідність інституціоналізації декларованих норм щодо землі та їі природних ресурсів як природних об'єктів права власності Українського народу 
(всіх громадян України) не лише після проголошення 16 липня 1990 р. Декларації про державний суверенітет України [12], але й після ухвалення 28 червня 1996 р. Конституції України [1] як незалежної держави.

У своєму дослідженні ми поглиблено обгрунтовуємо конституційні норми як норми прямої дії - що допоможе розв'язати існуючі загальнонаціональні проблеми, — як особливої передумови подальшого розвитку ринкових земельних відносин в агроландшафртах України і запровадити безапеляційну керованість стосовно подальшого раціонального використання всіх категорій земель в агроландшафтах як природних об'єктів права власності Українського народу.

Метою дослідження є поглиблення та обгрунтування основних передумов як особливих вимог загальнонаціонального значення стосовно бажаного подальшого розвитку ринкових земельних відносин в агроландшафтах України.

Матеріали та методи. Інформаційну основу дослідження становлять Конституція України, вітчизняні та міжнародні законодавчі і нормативні акти у сорері економіки природокористування, земельних відносин; матеріали і звіти Державної служби статистки України; Державної служби України з питань геодезії, картографії та кадастру; Державного земельного кадастру; наявні матеріали власного практичного досвіду. Для виконання поставлених завдань використовували такі методи досліджень: монографічний (опрацювання наукових публікацій і публікацій зі шпальт загальнонаціональної преси для обговорення громадськістю нормативних документів, статистичних даних); абстрактно-логічний (теоретичні узагальнення та фрормулювання висновків); аналізу та синтезу (обгрунтування методології системного дослідження) тощо.

Викладення основного матеріалу. В основі фрункціонування комфортної життєдіяльності людини як громадянина конкретної держави лежать природні чинники: земля (всі категорії земель) та її природні ресурси (вичерпні й невичерпні), живі мікроорганізми, сонячна, вітрова та інші енергії, що в процесі раціонального природокористування постійно (щорічно) створюють додану вартість і є головним, не позиченим інвестиційним природним капіталом нації - основним національним багатством. Ці чинники як природні об'єкти права власності Українського народу (всіх громадян України), що перебувають під особливою охороною держави, задекларовано в Конституції України (ст. 13-14) [1].

Доведено, що природна складова у ринковій вартості (кінцевої ціни) відповідного про- дукту (продукції), яку має одержувати власник (нація) у вигляді земельного податку чи рентної плати, становить вагому частку. Це зрозуміло, адже неможливо одержати продукти рослинництва (деревину, зерно, коренеплоди тощо) без сонячної енергії (процесу фотосинтезу), води, грунту, поживних речовин, мікробіоти тощо, так само, як метал — без руди (природної сировини), дорогоцінного каміння, природного газу, вугілля, будівельних матеріалів та інших корисних копалин (твердих, рідких і газоподібних) - без них самих.

На жаль, цю економічну аксіому перетворюють в політичну, і її оминають не лише «кандидати»на посади у владних структурах, а й корумповані чиновники та природокористувачі, посилаючись на всілякі схеми і «складні» розрахунки «ціноутворення». Вони стверджують, що частка природних ресурсів у ціні товару майже нульова, до того ж нація (держава) ще й повинна доплачувати (дотувати) їм. Такі необгрунтовані «бізнесові інтереси» виникають через постійне «взяття» влади і заниження (нівелювання) вартісної частки капіталу нації в ціні товару, а також відсутність наукового супроводу [13].

Натомість, через олігархічні телеканали і пресу нав'язується неправдива інформація, розповсюджується недовіра до всіх — до всього українського, до власної держави, її конституції.

Загалом, фрормується думка, особливо перед черговими виборами, що все робиться для того, щоб два найсакральніші конституційні права власності Українського народу (громадян України) «на землю» і «на владу» діяли б як мимобіжні чинники, і ніколи ці права не могли б повноцінно забезпечити їх приналежність громадянам.

Як наслідок, переважна більшість українців під «землею» дотепер розуміють — «поле», «грунт» і впевнені, що це право належить лише умовним «селянам», а «влада», немовби «поправу», має належати лише олігархічній «правлячій еліті». Так само продовжують думати майже всі кандидати - потім народні депутати України, та й більшість чиновників.

Однак на заваді вседозволеності стала, хоч і не завершена, хоч і недосконала земельна рефрорма в агросфрері, внаслідок чого з'явилися на землях сільськогосподарського призначення власники майже 7 млн земельних паїв (ділянок). 3 іншого боку, ім заважає, накладений мораторій, який діє впродовж 18 років і насправді, за мовчазної згоди і бездіяльності органів влади, тіньовий рух землі не вщухає.

Тому однією з найбільш гострих і дискусійних проблем, що точиться в суспільстві 
понад два десятиліття, є намагання відкрити легальний ринок (обіг) земель сільськогосподарського призначення і зняти мораторій, виключивши із цього процесу основного власника Український народ.

3 цією метою в Україні щедро фрінансуються різноманітні «експерти», які наполегливо розробляють різні варіанти такого ринку (обігу) землі.

10 квітня 2019 р. в Українському домі ГС «Всеукраїнська Аграрна Рада» провела Всеукраїнський земельний фрорум, на якому низка народних депутатів також презентували напрацьовані пропозиції щодо фрормування прозорого ринку землі.

Зокрема, замовчуючи запропоновану нами нову парадигму звершення комплексної земельної реформи в інтересах всіх громадян України, в т.ч. й селян, яка грунтується на вимогах конституційного прагматизму, а також маніпулюючи різними «аргументами» $\mathrm{i}$ «страхами», вони дійшли висновку, що «обгрунтований» ринок аграрної землі буде забезпечувати, начебто, рівні умови для всіх його «учасників» та діятиме на користь "українських фрермерів», що стануть реальними власниками «своєї землі».

Зовсім не згадувалося про необхідність введення здійснюваної дотепер земельної реформи в Україні в чинне конституційне поле і про виконання наведених вище першочергових заходів як особливих передумов інституціонального розвитку земельних відносин в Україні.

Натомість активізувалась улеслива інформаційна атака про, буцімто, наявність в їніх «командах» концепцій i, навіть, готової дорожньої карти та бачень майбутньої земельної рефрорми. Про це також йдеться публічно в Дзеркалі тижня «Задзеркалля та страхи земельної рефрорми. Час для рішень» [14].

До того ж суспільству нав'язується думка, що всі страхи власників землі як суб'єктів земельних відносин є необгрунтованими, оскільки «Концепція впровадження ринку землі», що передбачає необхідність втілення чотирьох законодавчих блоків, була обговорена з представниками МВФ, Світового банку, і представлена на зустрічі з громадянами-власниками паїв, аграріями та знайшла серед них загальну підтримку.

Відразу зауважимо, що такі «експерти», вмонтувавшись в списки різних політичних проектів, трактують необхідність найшвидшого впровадження «прозорого» і «комплексного» ринку землі як, начебто, узгоджену позицію із основними (на їхню думку) учасниками реформування земельних відносин.
Насправді серед таких «учасників» зовсім немає справжніх власників основного національного багатства всіх громадян України, в т.ч. працездатної молоді, яка може і хоче господарювати в природних агроландшафтах, але не є власниками (орендарями) земельних паїв (ділянок). Ця невідповідність нормам Конституції України вказує на те, що такі «команди» із «задзеркалля» мають на меті: «прозоро прибрати родючу землю до «своїх рук» , оскільки свідомо позбавляють можливості переважну більшість громадян України безпосередньо продавати чи купувати земельні ділянки, - хоча де-юре вони є основними учасниками реформування земельних відносин у державі.

Щоб вийти із такого стану, нами обгрунтовано нову парадигму звершення земельної рефрорми в Україні [15], де основою успішного розвитку i, водночас, зростаючого добробуту та комфрортної життєдіяльності її громадян є повноцінна реалізація конституційних норм щодо абсолютної власності Українського народу «на землю» як головного чинника об'єднуючого Конституційного прагматизму.

Зокрема доведено, що першопричиною негараздів є некоректність трактування терміна «земля». Тому, насамперед, кожен повинен усвідомити конституційну аксіому як істину двох основних сутностей права власності «на землю», що є нормами прямої дії, стосовно всіх категорій земель, а не лише земель сільськогосподарського призначення. Особливо, це стосується політиків, «владних мужів»і так званих «експертів» та всіх авторів публічного висловлювання з цієї тематики.

Нами доведено, що «землю та її природні ресурси» слід розглядати як природні об'єкти права власності Українського народу - основне національне багатство, що є капіталом всіх громадян України; а «земельну ділянку» як об'єкт цивільних прав, що перебуває у власності (державній, комунальній, приватній) i є капіталом її власника (держави, громади, громадянина чи юридичної особи) [16].

Також підкреслимо, що «земля» як природний об'єкти права власності Українського народу не може бути предметом купівлі-продажу, застави тощо і не підлягає відчуженню будь-ким, на користь будь-кого і в будь-який спосіб.

У іншому значенні «земля» як земельна ділянка (межа), що є об'єктом цивільних прав (нерухомістю) [17], навпаки, може бути предметом купівлі-продажу і підлягає відчуженню.

Оскільки господарська діяльність обумовлюється використанням природних об'єктів права власності Українського народу, вона може здійснюватися лише в процесі користу- 
вання (не володіння і не розпорядження) на платній основі за встановленими регламентами відповідно до закону, як цього вимагає ст. 13 Конституції України: «Кожний громадянин має право користуватися природними об'єктами права власності народу відповідно до закону». На жаль, такого закону досі немає. Його появу гальмують псевдо політикани і реформатори.

Важливо усвідомити, що вартісна частка природних об'єктів не може бути меншою від вартісної частки земельної ділянки (межі). Тому ця дійсність (контрольний пакет вартісної складової природного об'єкта), у процесі формування земельної ділянки як об'єкта цивільних прав і просторової основи здійснення господарської (підприємницької) діяльності в іï межах чи під час ринкового обігу, має узгоджуватися із суспільними інтересами. Адже вказана стаття Конституції України декларує: «Власність зобов'язує. Власність не повинна використовуватися на шкоду людині і суспільству».

Саме на такій основі конституційно гарантується громадянам, юридичним особам та державі набуття і реалізація прав власності на сорормовані земельні ділянки (землю) та господарювання на них, що виступають відповідними об'єктами не лише цивільних прав, а й обов'язків та вимог (регламентів) щодо природокористування і гарантій соціальної спрямованості економіки. Суб'єкти права власності (приватна, комунальна і державна) на земельні ділянки (землю) є рівними між собою та перед законом і не можуть конкурувати з правом власності Українського народу на природні об'єкти (землю).

Це дає можливість законно й відповідально (без ручного диктату чиновників) на конкурентній основі користуватися в межах «земельної ділянки» як уособленої господарської одиниці певними природними об'єктами з метою сталого і збалансованого здійснення: рільництва, садівництва, житлового, промислового та громадського будівництва, лісівництва, транспорту, зв' язку, енергетики, гірничо-видобувної промисловості, оборони, водно-господарської, природно-заповідної, природоохоронної, оздоровчої, рекреаційної історико-культурної та іншої діяльності.

Для цього нами пропонується першочергово ухвалити розроблюваний нами законопроект України «Про право користування природними об'єктами права власності Українського народу». Закон нормуватиме також роль головних природних чинників сонячної, вітрової та інших енергій, мікроелементів, мікробіоти й нерукотворного процесу фотосинтезу, які постійно (щорічно) створюють додану вартість, що є інвестиційним природним капіталом нації і становить абсолютну цінність. Такий не позичений капітал (кошти) має цілковито й реально належати українському народу і повинен працювати на розвиток економіки, підтримання екологічної рівноваги і зростання добробуту всіх громадян нашої держави, особливо тих, що проживають в сільській місцевості.

Центральне місце має займати просторове прогнозування й моделювання розвитку всіх територій та всіх категорій земель одночасно на всій території держави. Такий цілісний державний землевпорядний та архітектурно-будівельний процес - у розрізі територій місцевих рад базового рівня (у межах і поза межами населених пунктів), басейнів малих річок та їхніх водозборів має здійснюватися за безпосередньою участю місцевих громад та інститутів громадянського суспільства. Від початку звершення земельної реформи повинна здійснюватися тотальна діджиталізіція всіх кроків і наслідків - у часі і просторі.

Цей обов' язковий загальнонаціональний захід дасть змогу, насамперед, ідентифікувати і сертифікувати всі природні об'єкти, які мають некомерційну природно-заповідну, природоохоронну, оздоровчу, рекреаційну, історикокультурну та іншу цінність, виправити помилки здійснюваної колгоспно-радгоспної «рефрорми» і одночасно впорядкувати розпайовані землі сільськогосподарського призначення.

Зважаючи на глобальне потепління і необхідність невідкладного збереження довкілля в природних екосистемах, також, слід визначити всі ділянки, що мають грунтоводоохоронне значення і підлягають залуженню, залісенню та іншому освоєнню. Прогнозується вивести з інтенсивного землеробства понад 5 млн га угідь. До всіх цих та інших категорії земель мають встановлюватися адекватні (безапеляційні) регламенти (вимоги) з подальшого їх використання.

У разі невиконання цих вимог, всі ці площі підлягатимуть безпрецедентному виведенню із теперішнього стану для їх відновлення і прозорого та публічного аукціону щодо передачі відповідальним власникам-господарям.

Оскільки категорії природних об'єктів є своєрідними й неповторними, - в усіх без винятку природно-кліматичних зонах України, - їхн використання має максимально узгоджуватись із відповідним статусом (національного, регіонального, місцевого значення), для чого безперешкодно набувається право власності (користування) на відповідні земельні ділянки (межі), а саме на:

- нерукотворні природні об'єкти, що мають духовну (чудотворну), цілющу й життєдай- 
ну силу, історичну пам' ять і цінність (джерела, печери, скелі, балки, долини, купелі, парки, байраки, цвинтарі, місця перебування святих, преподобних, героїв тощо), не можуть використовуватися поза культовим духовним призначенням і тому мають перебувати в безстроковому (переважно в безоплатному) користуванні громад українського християнства та інших громад (етнічних меншин), які постійно проживають на певній території;

- інші природні об'єкти, що мають природно-заповідну, природоохоронну, оздоровчу, рекреаційну, історико-культурну та іншу цінність, що не можуть використовуватися поза відповідним цільовим призначенням і повинні перебувати у відповідному безстроковому користуванні (громадян, їхніх об'єднань, юридичних осіб тощо).

Наголосимо, одночасно і невідкладно слід розпочати оздоровлення сільських територій шляхом формування в сільській місцевості умов комфрортної життєдіяльності для молодих сімей, які зможуть одночасно бути власниками ефективних і заможних землеволодінь і землекористувань сімейного типу (малих і середніх фермерських господарств, родових маєтків тощо) як невід'ємних складових організму живого природного середовища та займалися б також різноманітним екологічно безпечним несільськогосподарським виробництвом і підприємництвом.

За таких умов досягається бажаний результат, коли в одній особі (громадянина України) одночасно концентрується і співвласник землі та її природних ресурсів (об'єкта права власності всього Українського народу), i власник земельної ділянки як об'єкта нерухомого майна, застосованої праці (розумової і фрізичної) та приватної ініціативи, власник продукції і вироблених ним же продуктів, у т.ч. інноваційних та інтелектуальних, власник знарядь, засобів і предметів, що беруть участь в життєдіяльності на відповідній території його самого (громадянина) та його сім'ї, а також повноцінний член громади [18].

Крім того, земле- та природокористувачі (місцеві громади) мають бути максимально заінтересовані в раціональному використанні землі та її природних ресурсів і у здійсненні контролю за збалансованим і сталим розвитком сільських територій та охороною довкілля.

Важливо, щоб українські християнські громади, які функціонують майже в кожному селищі та селі й духовно сприяють прихожанам утверджувати українську державність і громадянську самодостатність, долучалися до цього процесу і за бажанням організовували при сво- їх церквах господарства, зокрема об'єднуючи (орендуючи) земельні паї (ділянки).

За результатами наших досліджень, у сільській місцевості передбачено створити і впорядкувати (як варіант) понад 250 тис. приватних сімейних селянських (фермерських) господарств і господарств релігійних громад загальною площею в майже 10 млн га малих масивів орних земель та інших прилеглих угідь; майже 5 тис. спеціалізованих господарств різної фрорми господарювання (переважно з найманими працівниками) - загальною площею близько 10 млн га високотоварних великих масивів орних земель. Решту придатних угідь (існуючі та сорормовані) мають використовувати дрібні, особисті селянські та фермерські господарства (без найманих працівників).

Комфортна життєдіяльність усіх таких господарств як складових природно-господарської системи в конкретних природно-кліматичних умовах має грунтуватися на високоморальних та культурних цінностях і орієнтуватися на виробництво екологічно безпечної (органічної) високобілкової продукції рослинництва й тваринництва - за умови цілковитого збереження та підвищення природної родючості грунтів. Однією із головних передумов має бути вільний доступ до господарювання та безперешкодна самореалізація господарської приватної ініціативи й підприємництва - без посередників, дешеве довгострокове кредитування та гарантії збуту виробленої продукції за стабільними цінами - лише для громадян-учасників реалізації звершення земельної реформи в Україні, як невід'ємної складової нової державної політики.

Всьому цьому має передувати створення нової позавідомчої національної земельної установи України, що утворюватиметься за аналогією до Національного банку України. Вона виконуватиме роль утримувача капіталізованого основного національного багатства, яке є абсолютною власністю Українського народу, i гаранта прав власності на сорормовані земельні ділянки. В основі її діяльності буде достовірна і прозора багатофрнкціональна цифрова геоінформаційна система, що налічуватиме повноцінні кадастрові й реєстраційні системи.

Така установа як інститут, на відміну від інших, матиме свій бюджет та складовий рентний банк і виконуватиме багатоцільові функції та завдання, невластиві Національному банку України, державному бюджету України та комерційним банкам. Зокрема, супроводжуватиме фінансову підтримку звершення земельної рефрорми, а також сприятиме генеруванню Державного і місцевих бюджетів та золотовалютних запасів, продовольчої та 
енергетичної безпеки, збереженню цілісності території України, інших завдань національної безпеки тощо.

Реалізація цих та багатьох інших заходів звершення земельної реформи в Україні надасть змогу через два роки від початку ї повноцінного впровадження задіяти в ринкову економіку України доступні капіталізовані природно-ресурсні багатства, що в грошовому еквіваленті сумарно становитимуть лише десяту частину, або майже 9 трлн дол. США.

Прогнозується, що внаслідок раціонального використання природних ресурсів, щорічно надходитимуть в Національну земельну установу України (в розрізі районів і міст обласного підпорядкування) кошти у вигляді рентної плати чи земельного податку, в середньому на рівні $1 \%$ від їхньӧ загальної капіталізованої вартості. Ця сумарна величина становитиме на початковому етапі майже 90 млрд дол. США і збільшуватиметься щорічно.

Участь цього не позиченого капіталу, поряд із стрімким зростанням економіки України та регіональним розвитком, також стимулюватиме стабільність національної валюти і утримання облікової ставки Національного банку України на рівні близько $2 \%$ і гарантуватиме дешеве довгострокове кредитування — на рівні близько $3 \%$.

Висновки. Подальший розвиток ринкових земельних відносин і природокористування в агроландшафтах України є можливим за умов повноцінної інституціоналізації конституційної норми стосовно права власності Українського народу на землю та її природні ресурси як на природні об'єкти - основне національне багатство, що перебуває під особливою охороною держави.

Першочерговим заходом, як особливою передумовою інституціонального розвитку, має стати невідкладне введення здійснюваної дотепер земельної рефрорми в чинне конституційне поле України.

Проведення ідентифікації й сертифікації всіх природних об'єктів, особливо тих, що мають природно-заповідну, природоохоронну, оздоровчу, рекреаційну, історико-культурну та іншу цінність, а також виправлення помилок здійснюваної «колгоспно-радгоспної рефрорми» з одночасним впорядкуванням розпайованих земель сільськогосподарського призначення має відбуватись в процесі просторового прогнозування й моделювання розвитку всіх територій та всіх категорій земель одночасно на всій території держави.

Такий цілісний державний землевпорядний та архітектурно-будівельний процес у розрізі територій місцевих рад базового рівня (у межах і поза межами населених пунктів), басейнів малих річок та їхніх водозборів має здійснюватися за безпосередньою участю місцевих громад та інститутів громадянського суспільства. Від початку звершення земельної реформи повинна відбуватися тотальна діджиталізіція всіх кроків і наслідків - у часі і просторі.

Для зниження ризиків глобального потепління і невідкладного збереження та покращення стану довкілля в природних екосистемах передбачається визначити всі ділянки, що мають грунтоводоохоронне значення і підлягають залуженню, залісенню та іншому освоєнню. Прогнозується вивести з інтенсивного землеробства понад 5 млн га угідь. До всіх цих та інших категорій земель мають бути вжиті адекватні (безапеляційні) регламенти (вимоги) з подальшого їх використання.

Надважливою складовою відновлення сільських територій є фрормування у сільській місцевості умов комфрортної життєдіяльності для молодих сімей, які б одночасно були власниками ефективних і заможних землеволодінь і землекористувань сімейного типу (малих і середніх фермерських господарств, родових маєтків тощо) як невід'ємних складових організму живого природного середовища та займалися б різноманітним екологічно безпечним несільськогосподарським виробництвом і підприємництвом.

Лише після введення повноцінної земельної реформи в чинне конституційне поле України, а також виконання окреслених першочергових заходів як особливих передумов інституціонального розвитку земельних відносин і природокористування можна вести розмову про подальшу участь впорядкованих земель сільськогосподарського призначення в ринкових земельних відносинах в агроландшафтах України і про місце сьогоднішнього великого аграрного «бізнесу»в цьому процесі.

\section{СПИСОК ВИКОРИСТАНИХ ДЖЕРЕЛ}

1. Конституція України від 28 червня 1996 // Відомості Верховної Ради України), 1996, № 30. [Електронний ресурс]. Режим доступу: https://zakon.rada.gov.ua

2. Геєць B.M. Суспільство, держава, економіка: феноменологія взаємодії та розвитку. Київ: Інститут економіки та прогнозування НАН України, 2009. 864c.

3. Економічні, екологічні та соціальні аспекти використання земельних ресурсів в Україні: [колективна монографія]; за ред. О.В. Ульянченка. Х.: Смугаста типографія, 2015. 320 с. 
4. Конституція (Основний Закон) Української Радянської Соціалістичної Республіки. Верховна Рада УРСР; Конституція, Закон № 888-IX від 20.04.1978. [Електронний ресурс]. Режим доступу: http:// zakon1.rada.gov.ua/laws/show/888-09

5. Мартин А.Г. Регулювання ринку землі в Україні. К.: Аграр. Медіа груп. 2011. 254 с.

6. Добряк Д.С., Шкуратов О.І. Формування і розвиток ринкових земельних відносин на теренах України // Збалансоване природокористування. 2018. № 1. С. 8-17.

7. Заяць В.M. Розвиток ринку сільськогосподарських земель: [монографія]. К.: ННЦ «IAE», 2012.390 с.

8. Larsson G. Land Management: Public Policy, Control and Participation. Stockholm: SCBR, 1997. 232 p.

9. Шкуратов О.І. Оцінка земель в процесі організації екологічно орієнтованого сільськогосподарського виробництва // АгроСвіт. 2013. № 24. С. 13-17.

10. Євсюков Т.О. Класифікація та екобезпечне використання особливо цінних земель: монографія. КиївЛьвів: Ліга-Прес, 2015. 452 с.

11. Федоров M.M. Організаційно-економічні передумови формування ринку земель сільськогосподарського призначення // Економіка АПК. 2003. № 1. С. 25-31.

12. Декларація про державний суверенітет України № 55-XII від 16 липня 1990 року // Відомості Верховної Ради УРСР (ВВР), 1990, № 31, ст.429. [Електронний ресурс]. Режим доступу: http://zakon5. rada.gov.ua/laws/show/55-12

13. Ковалів О.І. Нові курси - старі схеми // Газета день. 2019. 27 лютого. С. 8.

14. Мірошніченко І.В. Задзеркалля та страхи земельної реформи. Час для рішень // Дзеркало тижня. 2019. 13-19 квітня. С. 8.

15. Ковалів О.І. Звершення земельної реформи в Україні: нова парадигма: [монографія]. К.: ДІА. 2016. 416 c.

16. Ковалів О.І. Особливості інституціонального забезпечення звершення земельної реформи в Україні // Збалансоване природокористування. 2017. № 1. С. 83-87.

17. Земельний кодекс України: 25 жовтня 2001 року № 2768-III // Відом. Верхов. Ради України (ВВР). 2002. № 3-4. С. 27. [Електронний ресурс]. Режим доступу: https://zakon.rada.gov.ua/laws/show/2768$14 /$ stru

18. Oleksander Kovaliv. Теоретично-методологічні засади звершення земельної редорми в Україні як нова парадигма. // WSPÓŁPRACA EUROPEJSKA, 2016. № 3(10). P. 35-47. [Електронний ресурс]. Режим доступу: http://we.clmconsulting.pl/index.php/we/article/view/142

\section{Індормація про автора}

Ковалів Олександер Іванович - доктор економічних наук, старший науковий співробітник, провідний науковий співробітник сектору економіки землекористування, Інститут агроекології і природокористування НАAН (Україна, 03143, м. Київ, вул. Метрологічна, 12; e-mail: okovaliv@ukr.net).

O.I. Kovaliv

Doctor Of Economic Sciences

Institute of Agroecology and Nature Management of NAAS

(Ukraine, Kyiv; e-mail: okovaliv@ukr.net)

\section{SPECIAL PRECONDITIONS FOR FURTHER DEVELOPMENT OF MARKET LAND RELATIONS IN AGRILATERAL PLANTS OF UKRAINE}

The current state of nature use beyond the boundaries of Ukrainian cities is described. The essence of the constitutional norm concerning the property rights of the Ukrainian people to the land and its natural resources as natural objects is revealed. The special prerequisites of institutional development of market land relations and nature use in agrolandscapes of Ukraine as the first priority measures are substantiated. The necessity of urgent introduction of land reform to date is proved - in the current constitutional field of Ukraine, ensuring the institutionalization of constitutional norms regarding the land and its natural resources as natural objects of the property rights of the Ukrainian people and the main national wealth, which is under special protection of the state. Established the necessity of identification and certification of all natural objects that have nature conservation, nature conservation, recreational, recreational, historical, cultural and other value. It is determined that in the process of implementation of the land reform in Ukraine, spatial forecasting and modeling of the development of all territories and all categories of land simultaneously throughout the state should take place in the central place. At the same time there should be a total dedjitalizatsii of all steps and consequences - in time and space. In order to reduce the risks of global warming and improve the environment, it is supposed to nurture and cover all areas of environmental significance. It is proposed to improve the countryside by creating a comfortable living environment for young families in rural areas, which at the same time would be the owners of efficient 
and wealthy economic land holdings and land uses of the family type (small and medium-sized farms, generic estates), which would also be engaged in a variety of environmentally friendly non-agricultural production and entrepreneurship.

Keywords: constitutional norms, nature management, land reform, land parcel, land shares, forecasting, land interests, market land relations.

\section{REFERENCES}

1. The Verkhovna Rada of Ukraine (1996), The Constitution of Ukraine. Retrieved from: https://zakon. rada.gov.ua (date of accesse: 20.12.2018).

2. Heyets', V.M. (2009). Suspil'stvo, derzhava, ekonomika: fenomenolohiya vzayemodiyi ta rozvytku [Society, state, economics: phenomenology of interaction and development]. Kyiv: Instytut ekonomiky ta prohnozuvannya NAN Ukrayiny. 864. (In Ukr.)

3. Ulianchenko, O.V. (Ed.). (2015). Ekonomichni, ekolohichni ta sotsial'ni aspekty vykorystannia zemel'nykh resursiv v Ukraini [Economical, ecological and social aspects and living land in Ukraine]. Kharkiv: Smuhasta typohrafiia. 320. (In Ukr.)

4. The Verkhovna Rada of USSR (1978), The Constitution (Basic Law) of the Ukrainian Soviet Socialist Republic. Retrieved from: http://zakon1.rada.gov.ua/laws/show/888-09 (date of accesse: 11.12.2018).

5. Martyn, A.H. (2011). Rehulyuvannya rynku zemli v Ukrayini [Rehulyuvannya rynku zemli v Ukrayini]. K.: Ahrar. Media hrup. 254. (In Ukr.)

6. Dobryak, D.S. \& Shkuratov, O.I. (2018). Formuvannya i rozvytok rynkovykh zemel'nykh vidnosyn na terenakh Ukrayiny [Formation and development of market land relations in Ukraine]. Zbalansovane pryrodokorystuvannya [Balanced Nature Using], 1. 8-17. (In Ukr.)

7. Zayats, V.M. (2012). Rozvytok rynku sil's'kohospodars'kykh zemel' [Development of agricultural land market]. K.: NSC «IAE». 390. (In Ukr.)

8. Larsson, G. (1997). Land Management: Public Policy, Control and Participation. Stockholm: SCBR. 232 p.

9. Shkuratov, O.I. (2013). Otsinka zemel' v protsesi orhanizatsii ekolohichno oriientovanoho sil's'kohospodars'koho vyrobnytstva [Assessment of land in the process of organizing environmentally friendly agricultural production]. AgroSvit [Agrosvit], 24.13-17. (In Ukr.)

10. Yevsiukov, T.O. (2015). Klasyfikatsiia ta ekobezpechne vykorystannia osoblyvo tsinnykh zemel' [Classification and eco-friendly use of high-value land]. Kyiv-L'viv: Liha-Pres. 452. (In Ukr.)

11. Fedorov, M.M. (2003). Orhanizatsiyno-ekonomichni peredumovy formuvannya rynku zemel' sil's'kohospodars'koho pryznachennya [Organizational and economic prerequisites for the formation of the market of agricultural land]. Ekonomika APK [The Economy of Agro-Industrial Complex], 1. 25-31. (In Ukr.)

12. The Verkhovna Rada of USSR (1990), Declaration on State Sovereignty of Ukraine. Retrieved from: http://zakon5.rada.gov.ua/laws/show/55-12 (date of accesse: 03.12.2018).

13. Kovaliv, O.I. (2019). Novi kursy — stari skhemy [New Courses — Old Circuits]. Hazeta Den [Newspaper Day]. $27 / 02$. 8. (In Ukr.)

14. Miroshnichenko, I.V. (2019). Zadzercallj ta strahy zeme l'noi' reform. Chas dl'j risheni' [Mirrors and fears of land reform. Time for decisions]. Dzerkalo Tyzhnia [Mirror of the Week], 13-19/04. 8. (In Ukr.)

15. Kovaliv, O.I. (2016). Zvershennia zemel'noi reformy v Ukraini: nova paradyhma [Completion of land reform in Ukraine: a new paradigm]. K.: DIA. 416. (In Ukr.)

16. Kovaliv, O.I. (2017). Osoblyvosti instytutsional'noho zabezpechennia zvershennia zemel'noi reformy v Ukraini [Features of institutional support for the implementation of land reform in Ukraine]. Zbalansovane pryrodokorystuvannia [Balanced Nature Using], 1. 83-87. (In Ukr.)

17. The Verkhovna Rada of Ukraine (2001), The Land Code of Ukraine. Retrieved from: https://zakon. rada.gov.ua/laws/show/2768-14/stru (date of accesse: 09.12.2018).

18. Kovaliv, O.I. (2016). Teoretyko-metodolohichni zasady zvershennia zemel'noi reformy v Ukraini jk novoi paradyhmy [Theoretical and methodological foundations of land reform completion as a new paradigm in Ukraine]. Współpraca Europejska, 3(10). 35-47. Retrieved from: http://we.clmconsulting.pl/index. $\mathrm{php} /$

\section{Author}

Kovaliv Oleksander Ivanovych - Doctor of Economics Sciences, Senior Researcher, Leading Researcher of Sector of Land Use Economics, Institute of Agroecology and Nature Management, NAAS (Ukraine, 03143, Kyiv, 12 Metrologichna St.; e-mail: okovaliv@ukr.net). 